\title{
Acute Abdomen Secondary to Ruptured Epithelial Ovarian Cancer during Pregnancy: The Relevance of Teamwork
}

\section{Abdome agudo secundário à ruptura do câncer do ovário epitelial durante a gravidez: a importância do trabalho em equipe}

Carlos Manuel Ortiz-Mendoza ${ }^{1}$ Sandra Adriana Vera-Vázquez ${ }^{2}$ Manuel Gómez-Rodríguez² José Luis López-Gómez ${ }^{3}$ Leticia Bornstein-Quevedo ${ }^{4}$

${ }^{1}$ Department of Surgical Oncology, Centro Médico Dalinde, México, DF, Mexico

2 Department of Obstetrics and Gynecology, Hospital Ángeles México, México, DF, Mexico

${ }^{3}$ Department of Anesthesiology, Hospital Ángeles México, México, DF, Mexico

${ }^{4}$ Department of Pathology, Hospital San Ángel Inn Universidad, México, DF, Mexico

Rev Bras Ginecol Obstet 2017;39:513-515.

Address for correspondence Carlos Manuel Ortiz-Mendoza, MD, Centro Médico Dalinde, Tuxpan \#29, office 516, Col. Roma Sur, CP 06760, Deleg. Cuauhtémoc, México, DF, Mexico (e-mail: cortizmendoza@yahoo.com.mx).

\begin{abstract}
Keywords

- acute abdomen

- epithelial ovarian cancer

- ovarian cancer

- pregnancy

- ruptured epithelial ovarian cancer
\end{abstract}

\section{Resumo}

Acute abdomen secondary to epithelial ovarian cancer rupture during pregnancy is a rare event. Our aim is to present how the work of a coordinated multidisciplinary team in a case of ruptured epithelial ovarian cancer during pregnancy is feasible to obtain the best results possible. A 34-year-old woman during the 37th week of her first gestation presented with an acute abdomen. During laparotomy, a ruptured $16.5-\mathrm{cm}$ left ovarian tumor was detected; the tumor was extirpated and sent to pathologic evaluation. In the meantime, a Kerr cesarean section was performed, and a healthy female neonate was born. The tumor was diagnosed as a cystadenocarcinoma; therefore, the family and the combined surgical team (obstetricians and a surgical oncologist) decided to complete a definitive radical ovarian cancer surgery: hysterectomy, right salpingooophorectomy, lymphadenectomy, omentectomy and appendectomy. The patient's postoperative evolution was uneventful, and she was sent to adjuvant chemotherapy.

O abdome agudo secundário à ruptura do câncer do ovário epitelial durante a gravidez é um evento raro. Nosso objetivo é apresentar como o trabalho de uma equipe multidisciplinar coordenada em um caso de ruptura do câncer de ovário epitelial durante a gravidez é viável para obter os melhores resultados possíveis. Uma mulher de 34 anos de idade, durante a $37^{\mathrm{a}}$ semana de sua primeira gestação, apresentou um received

February 13, 2017

accepted

April 19, 2017

published online

June 23, 2017
DOI https://doi.org/

10.1055/s-0037-1604028.

ISSN 0100-7203.
Copyright $(2017$ by Thieme Revinter

Publicações Ltda, Rio de Janeiro, Brazil
License terms

(ㄷ) (i) $\ominus$ (5) 


\section{Palavras-chave}

- abdome agudo

- câncer de ovário epitelial

- cancro do ovário

- gravidez

- ruptura do câncer abdome agudo. Durante a laparotomia, foi detectado um tumor ovariano esquerdo com ruptura de $16,5 \mathrm{~cm}$; O tumor foi extirpado e enviado para avaliação patológica. Enquanto isso, uma cesariana de Kerr foi feita, e uma recém-nascida saudável nasceu. $\mathrm{O}$ tumor foi diagnosticado como um cistoadenocarcinoma; então, a família e a equipe cirúrgica combinada (obstetras e oncologista cirúrgico) decidiram concluir uma cirurgia radical definitiva do câncer de ovário: histerectomia, salpingo-ooforectomia direita, linfadenectomia, omentectomia e apendicectomia. A evolução pós-operatória da paciente foi sem intercorrências, e ela foi enviada para quimioterapia adjuvante.

\section{Introduction}

When an acute abdomen occurs during pregnancy, it poses a huge challenge. ${ }^{1}$ However, an acute abdomen caused by a ruptured epithelial ovarian cancer during pregnancy is an exceptional disorder. ${ }^{2,3}$ Our aim is to present how the work of a coordinated multidisciplinary team in a case of ruptured epithelial ovarian cancer during pregnancy is feasible.

\section{Case Description}

A 34-year-old woman during the 37th week of her first gestation called her obstetrician because she felt an acute abdominal pain. The patient stated that the pain was sharp, and its intensity increased until it became incapacitating; her physician recommended that she presented to an emergency room immediately. In the meantime, the obstetrician called the surgical oncologist to inform that the patient was in the 37th week of her first gestation and, additionally, she had a big-papillary left ovarian tumor, discovered during her last abdominal ultrasound. Both physicians agreed to evaluate the patient; in the emergency room, the patient presented an evident acute abdomen, and the physicians decided for an immediate laparotomy. Using epidural anesthesia, during the laparotomy, a ruptured $16.5-\mathrm{cm}$ leftovarian tumor, with intraperitoneal spillage of its inner
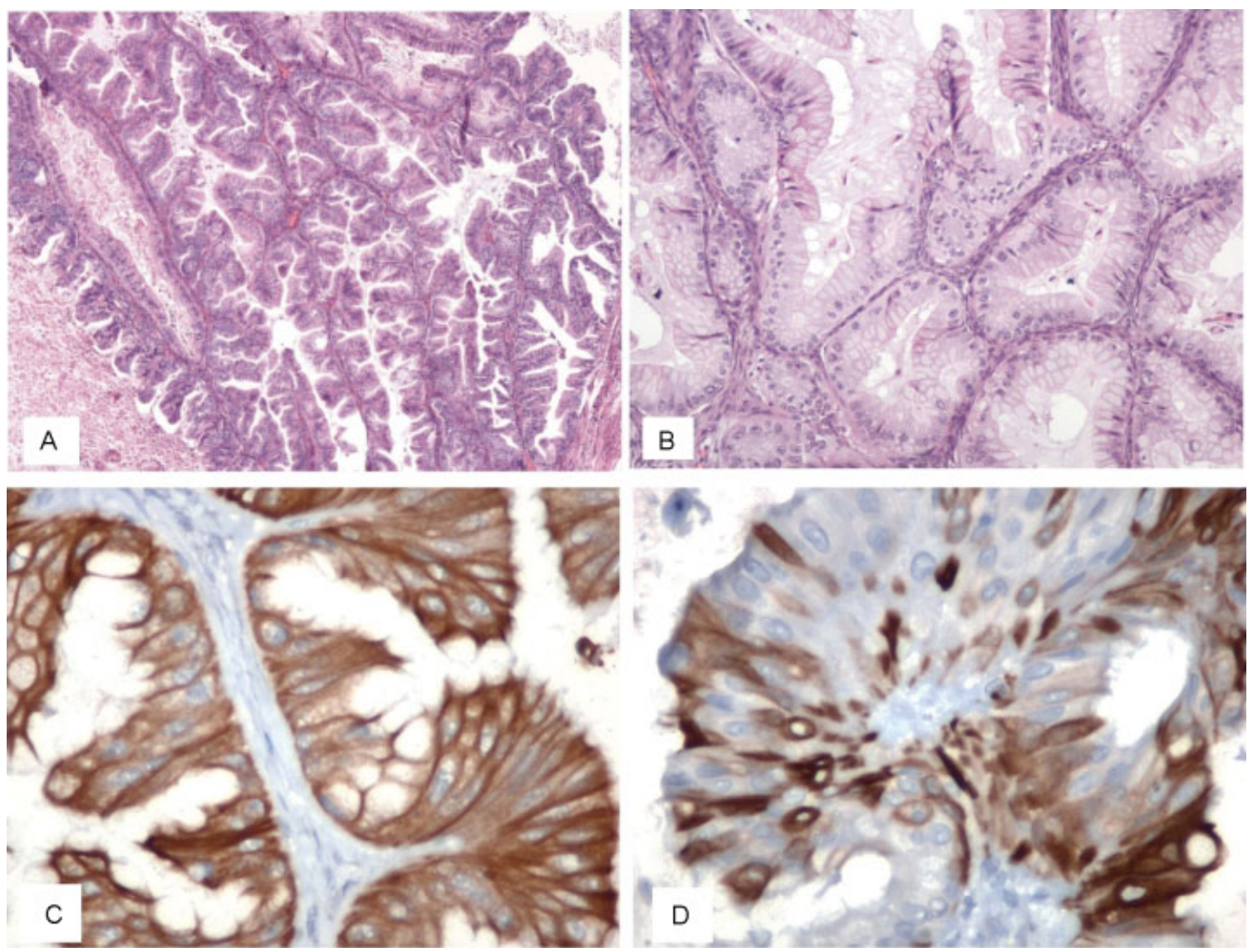

Fig. 1 (A) Photomicrograph of a hematoxylin and eosin-stained section (4x) showing abundant tumor papillae; (B) photomicrograph of a hematoxylin and eosin-stained section (10x) showing goblet cells with nuclear stratification; (C) photomicrograph of cytokeratin CK7 immunohistochemistry (40x); (D) photomicrograph of cytokeratin CK20 immunohistochemistry (40x). 
liquid, was recognized; through the broken tumor wall, many big papillae were observed. A sample from the liquid was taken, and a left salpingo-oophorectomy was completed, and both specimens were sent to the pathology department (at $1 \mathrm{am}$ ) for a transoperatory examination. In the meantime, a Kerr cesarean section was performed, and a healthy female neonate weighing $2.35 \mathrm{~kg}$ was born. The pathologist diagnosed a ruptured cystadenocarcinoma. With this diagnosis, the patient's husband and the combined surgical team (obstetricians and a surgical oncologist) decided to complete an ovarian carcinoma routine: hysterectomy, right salpingooophorectomy, pelvic and para-aortic lymphadenectomy, infracolic omentectomy and appendectomy, with no gross residual tumor; the patient's postoperative evolution was uneventful. The definitive pathologic report was a ruptured moderately differentiated mucinous cystadenocarcinoma (-Fig. 1), without tumor capsule invasion and with no metastases to the other surgical specimens. The patient received 6 cycles of carboplatin plus paclitaxel; by the end of the treatment, the patient was well, without tumor recurrence 15 months later.

\section{Discussion}

To our best knowledge, after an extensive literature review (in the PubMed, Google Scholar, LILACS, and Scopus databases), this is the first case of a ruptured epithelial ovarian cystadenocarcinoma during pregnancy favorably resolved in the primary surgery with a cesarean section and a radical surgical procedure. There are two previous reports, one of an endometrioid ovarian carcinoma, and the other of a mucinous cystadenocarcinoma, of cases that presented with rupture during pregnancy ${ }^{4,5}$, and in both cases, definitive diagnosis and surgical radical treatment for ovarian cancer were performed after the emergency was solved. ${ }^{4,5}$

Acute abdominal pain during pregnancy entails a huge challenge, ${ }^{1}$ and when indicated according to specific clinical features, laparotomy is the best way to preserve the lives of the mother and the fetus. ${ }^{1}$ However, oncologic procedures during pregnancy are an enormous challenge.

It is well known that, among non-pregnant women, radical surgical cyto-reduction and adjuvant chemotherapy are the standard of care for epithelial ovarian cancer. ${ }^{6,7}$ However, these tumors during pregnancy are rare, and due to their infrequency, a lot of questions regarding the treatment are pending. Thus, each case of epithelial ovarian cancer during pregnancy needs to be treated individually. ${ }^{6,7}$ According to some authors, due to increasing maternal age rates worldwide, an increase in the prevalence of cancers complicating pregnancies is soon expected. ${ }^{2,3,8}$ Considering the product well-being, a complete radical surgery for ovarian cancer during pregnancy in the primary surgery has not been previously reported. $^{7}$

\section{Conclusion}

A multidisciplinary team working closely in the management of ovarian cancer during pregnancy is of paramount importance to obtain the best possible results ${ }^{7,9}$, like in the case presented in this study.

\section{Ethical Standards}

Disclosure of potential conflicts of interest: the authors have no conflicts of interest to declare.

\section{Funding}

This study did not receive any funding.

\section{Informed Consent}

Informed consent was obtained from the patient.

\section{Contributions}

All of the manuscript authors made substantial contributions to the conception, design, development, and draft of the article, and all read and agreed with the manuscript's final version submitted to RBGO.

\section{References}

1 Nair U. Acute abdomen and abdominal pain in pregnancy. Curr Obstet Gynaecol 2005;15(06):359-367

2 Salani R, Billingsley CC, Crafton SM. Cancer and pregnancy: an overview for obstetricians and gynecologists. Am J Obstet Gynecol 2014;211(01):7-14

3 Goh W, Bohrer J, Zalud I. Management of the adnexal mass in pregnancy. Curr Opin Obstet Gynecol 2014;26(02):49-53

4 Gottheil S, McGee J. Endometrioid ovarian carcinoma during pregnancy presenting with acute rupture. J Obstet Gynaecol Can 2013;35(11):1020-1022

5 Malhotra N, Sumana G, Singh A, Deka D, Mittal S. Rupture of a malignant ovarian tumor in pregnancy presenting as acute abdomen. Arch Gynecol Obstet 2010;281(05):959-961

6 Grimm D, Woelber L, Trillsch F, Keller-v Amsberg G, Mahner S. Clinical management of epithelial ovarian cancer during pregnancy. Eur J Cancer 2014;50(05):963-971

7 Blake EA, Kodama M, Yunokawa M, et al. Feto-maternal outcomes of pregnancy complicated by epithelial ovarian cancer: a systematic review of literature. Eur J Obstet Gynecol Reprod Biol 2015;186:97-105

8 Saeed Z, Shafi M. Cancer in pregnancy. Obstetrics, Gynaecol Reprod Med 2011;21(07):183-189

9 Cooke L, Shafi MI. Cancer in pregnancy. Obstetrics, Gynaecol Reprod Med 2013;23(10):317-319 